\title{
Intrasporangial Germination and Outgrowth of Bacillus subtilis Prespores
}

\author{
By P. DION, D. KAY AND J. MANDELSTAM \\ Microbiology Unit, Department of Biochemistry, and Sir William Dunn \\ School of Pathology, South Parks Road, Oxford OX1 3QU
}

(Received 2 March 1978)

\begin{abstract}
Heat-sensitive prespores of Bacillus subtilis have been induced to germinate and outgrow while they are still enclosed within the mother cell. This intrasporangial germination has been obtained by transferring sporulating cells to rich medium after treatment with phenylmethylsulphonyl fluoride or toluene, or after subjecting them to cold-shock. The morphology of intrasporangial germination and outgrowth is described, and some possible explanations of the phenomenon are considered.
\end{abstract}

\section{INTRODUCTION}

Endospore formation in Bacillus spp. normally occurs under conditions of nutrient limitation. Sporulating cells respond in different ways to a subsequent enrichment of the medium, depending upon the stage of sporulation that they have reached. In Bacillus subtilis, if enrichment occurs during the early stages, sporulation is inhibited and the mother cell resumes vegetative growth (Frehel \& Ryter, 1969). Later, however, endospore formation reaches a point where it is not immediately inhibited by the addition of nutrients; the cells are then committed to continue sporulation, at least for a while (Frehel \& Ryter, 1969; Sterlini \& Mandelstam, 1969). Hence, during sporulation, cells lose the capacity to respond rapidly to enrichment and the time at which this occurs in $B$. subtilis depends on the type of nutrient added (Cooney et al., 1977). The critical time with regard to the growth potential of the mother cell seems to be that at which engulfed prespores are produced (Frehel \& Ryter, 1969; Freese \& Freese, 1977).

Engulfment is followed some time later by the acquisition of germination potential by the developing prespore. Thus, it has been observed that incomplete, i.e. heat-sensitive, spores of Bacillus spp. (probably at stage IV to $\mathrm{V}$ of development) are capable of germinative responses (Lundgren et al., 1969; Ellar et al., 1975).

However, intrasporangial outgrowth of prespores following enrichment has not apparently been shown. Three explanations are possible: (i) that the prespore lacks some component needed for germination and outgrowth; (ii) that the sporangium contains an inhibitor of germination and outgrowth; (iii) that the mother cell prevents access of germinants. None of these explanations necessarily excludes any of the others.

Here we show that, under appropriate conditions, enrichment of the medium allows intrasporangial outgrowth of prespores from at least stage IV onwards so that the spores, at that stage at least, must contain the metabolic components necessary for vegetative growth. Intrasporangial germination and outgrowth were obtained by first subjecting sporulating cultures to cold-shock or to toluene treatment at about the time of spore cortex synthesis (stage IV), or else by treating them with phenylmethylsulphonyl flucride, an inhibitor of serine proteases. The cells were then exposed to a rich medium. 


\section{METHODS}

Bacillus subtilis 168 (trpC2) was grown in a hydrolysed casein medium ( $\mathrm{CH}$ medium) (Sterlini \& Mandelstam, 1969). Exponentially growing cultures were harvested when they contained $0.25 \mathrm{mg}$ dry wt bacteria $\mathrm{ml}^{-1}$ and sporulation was induced by transferring the cells to a resuspension medium containing glutamate, tryptophan and salts (Sterlini \& Mandelstam, 1969). Time (h) after resuspension is denoted $t 1, t 2$ etc. The cytological stages of spore formation have been described by Ryter (1965). In this paper, the cell enclosing the developing prespore is called the 'mother cell'. The structure comprising the prespore and the mother cell is called the 'sporangium'.

Procedures for sporulation experiments involving phenylmethylsulphonyl fluoride (PMSF) have been described by Dancer \& Mandelstam (1975). A saturating amount (4 mg ml-1) of inhibitor was added at about $t 3$, when approximately $10 \%$ of the cells contained phase-grey spores. For reasons explained in the Discussion, the experiments with PMSF were done at $42{ }^{\circ} \mathrm{C}$. In other experiments the incubation temperature was $37^{\circ} \mathrm{C}$.

$\mathrm{CH}$ medium or brain heart infusion broth (Difco) containing $0.5 \%(\mathrm{w} / \mathrm{v})$ yeast extract (BHIB) were used as outgrowth media. Microscope slides coated with agar were used for slide cultures. The agar was prepared from brain heart infusion broth (Difco) to which Lab M agar (London Analytical and Bacterio-

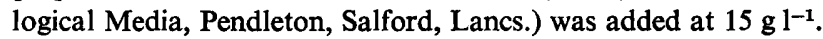

Electron microscopic techniques have been described elsewhere (Kay \& Warren, 1968). Phase-contrast photographs were taken using a Zeiss model NF microscope. In this paper, the term 'phase-bright' applies to all gradations from dull white to bright spores; the term 'phase-grey' applies to any darker sporal inclusion.

To measure heat-resistance, the culture was heated at $80^{\circ} \mathrm{C}$ for $15 \mathrm{~min}$ and dilutions were plated on nutrient agar (Difco). For estimation of toluene-resistance, a drop of toluene was added to $1 \mathrm{ml}$ of culture in a test tube. The tube was then shaken for $1 \mathrm{~min}$ and dilutions were plated on nutrient agar.

\section{RESULTS}

Intrasporangial germination of prespores following cold-shock and enrichment of the medium

Bacteria were grown in $\mathrm{CH}$ medium at $37^{\circ} \mathrm{C}$ and then transferred to resuspension medium also at $37^{\circ} \mathrm{C}$. At about $t 4.5$ [when between 10 and $30 \%$ of the cells contained phase-bright spores and a negligible number of heat-resistant spores $\left(10^{3}\right.$ to $\left.10^{5} \mathrm{ml}^{-1}\right)$ were present] the culture was shaken for $15 \mathrm{~min}$ in a water bath at $0{ }^{\circ} \mathrm{C}$. The cells were then resuspended in warm BHIB $\left(37^{\circ} \mathrm{C}\right)$ and further incubated at $37^{\circ} \mathrm{C}$. Rapid intrasporangial phase-darkening of the spores was observed. This was correlated with a $90 \%$ decrease in toluene-resistance that was largely complete within $30 \mathrm{~min}$. When a control culture, which had not been cooled, was resuspended in BHIB, there was only a $10 \%$ decrease in toluene-resistance (Table 1).

Table 1. Effect of resuspension in BHIB on the toluene-resistance of sporulating cells

$\begin{array}{lcc} & \begin{array}{c}\text { Time } \\ \text { after resuspension } \\ (\mathrm{min})\end{array} & \begin{array}{c}\text { Toluene-resistance } \\ \left(10^{-7} \times \text { c.f.u. } \mathrm{ml}^{-1}\right)\end{array} \\ \text { Cells not cold-shocked before resuspension } & 0 & 9 \cdot 0 \\ \text { Cells cold-shocked* before resuspension } & 30 & 8 \cdot 2 \\ & 0 & 8 \cdot 2 \\ & 30 & 0 \cdot 4\end{array}$

* Cold-shock: $0{ }^{\circ} \mathrm{C}$ for $15 \mathrm{~min}$, the cells remaining in their sporulation medium. 


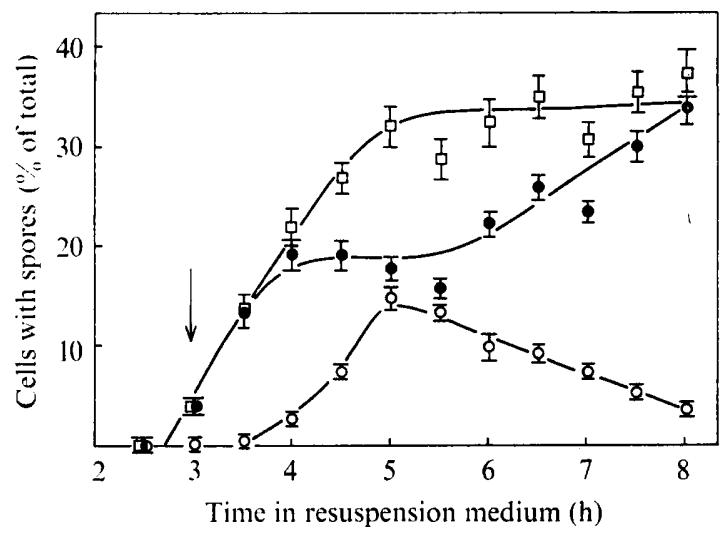

Fig. 1. Bacillus subtilis 168 was grown in $\mathrm{CH}$ medium at $42^{\circ} \mathrm{C}$ and transferred to resuspension medium also at $42{ }^{\circ} \mathrm{C}$. At $t 3$ (indicated by the arrow) a saturating amount of PMSF ( $4 \mathrm{mg} \mathrm{ml}^{-1}$ ) was added.

$\bigcirc$, Phase-bright spores; $\bullet$, phase-grey spores; $\square$, total number of spores, given by the sum of the numbers of phase-bright and of phase-grey spores at each time.

\section{Intrasporangial germination of prespores following treatment with PMSF}

Bacteria were grown in $\mathrm{CH}$ medium at $42{ }^{\circ} \mathrm{C}$ and then transferred to resuspension medium also at $42^{\circ} \mathrm{C}$. At about $t 3$ (soon after phase-grey spores had begun to appear) a saturating amount $\left(4 \mathrm{mg} \mathrm{ml}^{-1}\right)$ of PMSF was added. Under these conditions the proportion of cells with phase-bright spores reached a maximum (about $15 \%$ ) at $t 5$ (Fig. 1). After $t 5$, the proportion of cells containing phase-bright spores decreased and there was a concomitant increase in the proportion of cells showing phase-grey spores, so that the overall proportion of cells with a sporal inclusion remained constant. During a similar experiment, the heatresistance of the PMSF-treated culture was about $1 \%$ of that in the untreated control. There thus appeared to be a transition from phase-bright to phase-grey spores when sporulating cells were incubated in the presence of PMSF (Fig. 1).

\section{Intrasporangial germination of prespores following treatment with PMSF and enrichment of the medium}

It seemed likely that the phase-darkening could be accelerated by treating the cells with PMSF and resuspending them in a rich medium. In order to do this, PMSF was added at $t 3$ to a culture sporulating at $42{ }^{\circ} \mathrm{C}$. At $t 6$ (when 10 to $20 \%$ of the cells contained phase-bright spores) the culture was passed through a coarse glass sinter to remove the PMSF crystals, resuspended in fresh CH medium or BHIB and further incubated at $42{ }^{\circ} \mathrm{C}$. After incubation for $30 \mathrm{~min}$ in rich medium, the number of cells containing phase-bright spores had fallen to less than $1 \%$. In a control culture which had been left in PMSFcontaining medium, 10 to $20 \%$ of the cells contained phase-bright spores.

\section{Phase-contrast observations on intrasporangial germination and outgrowth following cold-shock and enrichment of the medium}

When cold-shocked cells were resuspended in rich medium, phase-darkening was followed by intrasporangial outgrowth. Germination and outgrowth of individual prespores, while they still remained inside the mother cell, were studied by phase-contrast observation of immobilized cells from slide cultures. After phase-darkening the prespore was barely distinguishable from the mother cell. After about $4 \mathrm{~h}$ at room temperature, a 'phase-bright end' developed, usually at the end opposite to the germinated spore. At about $7 \mathrm{~h}$ the 


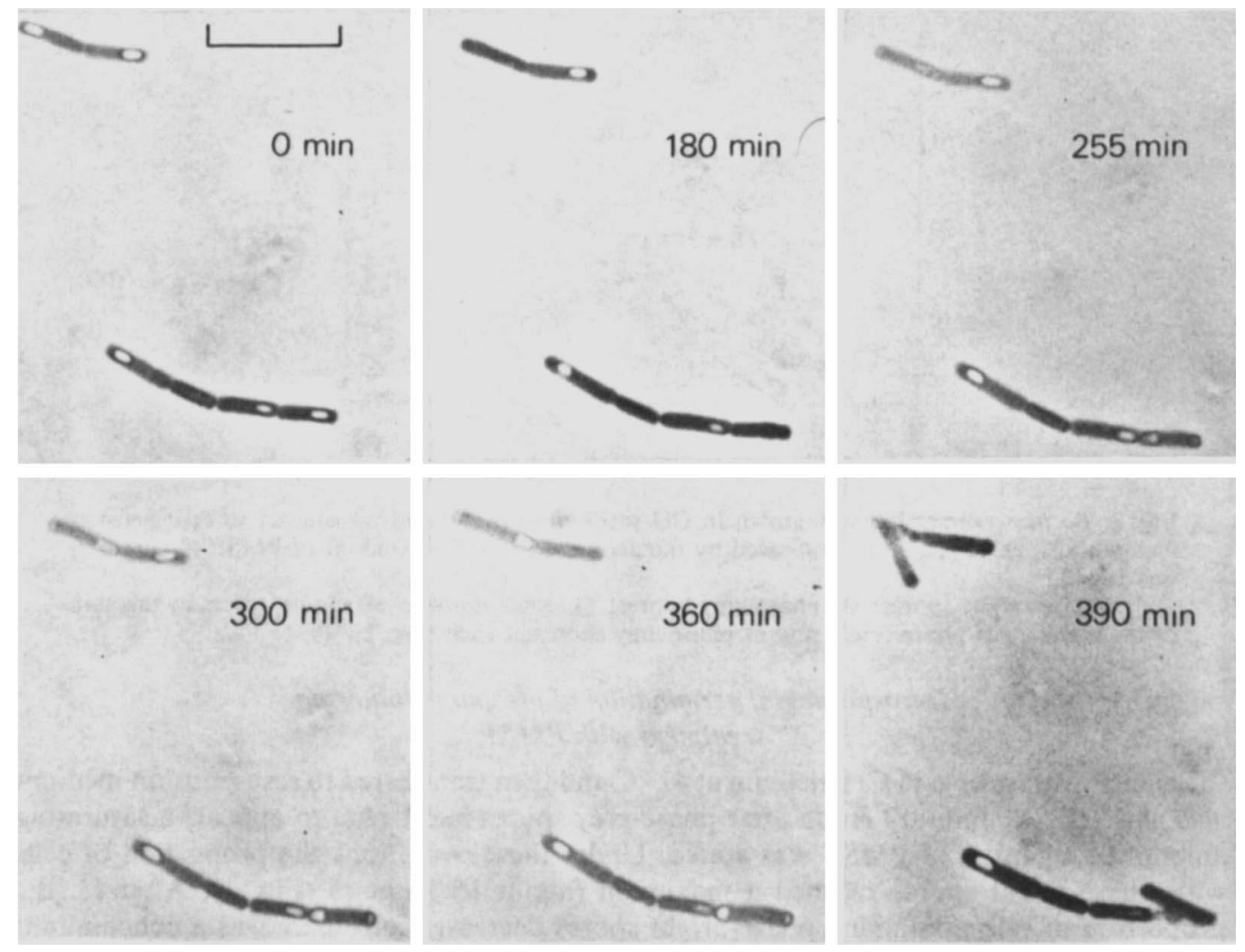

Fig. 2. Bacillus subtilis 168 was grown in $\mathrm{CH}$ medium at $37^{\circ} \mathrm{C}$ and transferred to resuspension medium also at $37^{\circ} \mathrm{C}$. At $t 4.5$ the cells were cold-shocked (see text) and transferred to a slide culture on brain heart infusion agar. Further incubation was at room temperature. Bright spores were present immediately after transfer $(0 \mathrm{~min})$. Some of them then darkened until they could not be distinguished within the mother cell $(180 \mathrm{~min})$. New phase-bright areas began to develop inside the sporangia, usually more markedly at the end opposite to the one where the spore was located ( $255 \mathrm{~min})$. 'Phase-bright ends' (see text) became clearly visible (300 $\mathrm{min}$ ) and the sporangia elongated slightly $(360 \mathrm{~min})$. The sporangia then burst, liberating the outgrown cells $(390 \mathrm{~min})$. Bar marker represents $5 \mu \mathrm{m}$.

outgrown spore forced its way through the wall of the mother cell. The rupture of the mother cell could be seen as a sudden, 'explosive' event, occurring within a second or two. The remains of the mother cell, with a newly developed cell emerging from it, usually at an acute angle, could then be observed (Fig. 2).

In PMSF-treated cells the time course and appearance of outgrowth were similar.

\section{Electron microscopy of intrasporangial outgrowth}

Electron microscopy revealed further details of prespore outgrowth. At the time of cooling ( $t 4.5)$ most spores had reached stage IV, some being surrounded by a germ cell wall only, while in others the cortex (lightly stained layer) was more fully developed (Fig. 3a). After cold-shock and resuspension in BHIB at $37^{\circ} \mathrm{C}$, the chilled prespores elongated and eventually appeared as small vegetative cells inside the mother cell (Fig. $3 b, c$ ). Some darkly stained material was observed at the ends of the mother cells after about $1 \mathrm{~h}$ incubation in BHIB (Fig. $3 b, c$ ). This appeared to be spore coat material. As coat layers could not be observed before the cells were cold-shocked (Fig. $3 a$ ), it seems likely that coat deposition had occurred while the prespores were undergoing outgrowth (see Discussion). 

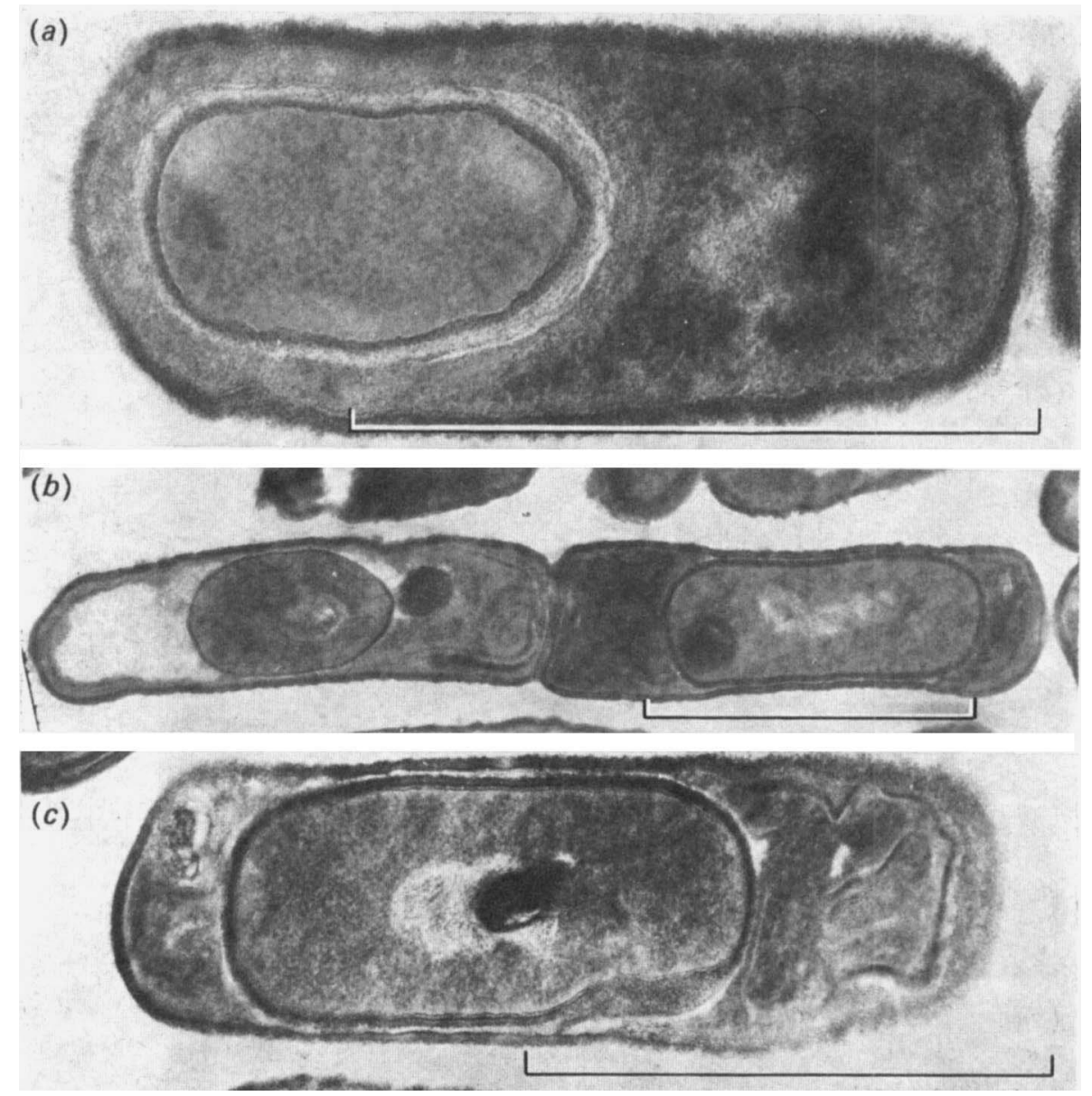

Fig. 3. Bacillus subtilis 168 was grown in $\mathrm{CH}$ medium at $37^{\circ} \mathrm{C}$ and transferred to resuspension medium also at $37^{\circ} \mathrm{C}$. At $t 4.5$ the cells were cold-shocked (see text) and resuspended in BHIB. Further incubation was at $37^{\circ} \mathrm{C}$. (a) A sporulating cell at $t 4.5$ and before cold-shock, which has reached stage IV. (b) Two sister prespores undergoing intrasporangial outgrowth, $65 \mathrm{~min}$ after resuspension in BHIB. (c) A single prespore undergoing intrasporangial outgrowth, $75 \mathrm{~min}$ after resuspension in BHIB. The ends of the mother cells shown in $(b)$ and $(c)$ contain some darkly stained material which appears to be spore coat material. In $(b)$ the dark-staining round bodies are mesosomes. Bar markers represent $1 \mu \mathrm{m}$.

When PMSF-treated cells were examined in the same way, it was found that most spores were enclosed by a coat layer (dark-staining layer) (Fig. 4 a). After resuspension of the cells in $\mathrm{CH}$ medium $\left(42^{\circ} \mathrm{C}\right)$ and subsequent intrasporangial germination (which did not markedly affect their appearance in the electron microscope), the spores began to elongate. Newly developed cells, still inside the mother cells, were then observed. Eventually the walls of the mother cells ruptured, releasing the new cells still attached to the spore coats (Fig. $4 b, c$ ). Remnants of the lysed mother cells could also be seen attached to the broken spore coats (Fig. $4 b, c$ ). Figure $4(d)$ shows a prespore that has developed into a cell, and this has formed an incipient cell division septum while remaining enclosed by the mother cell. 

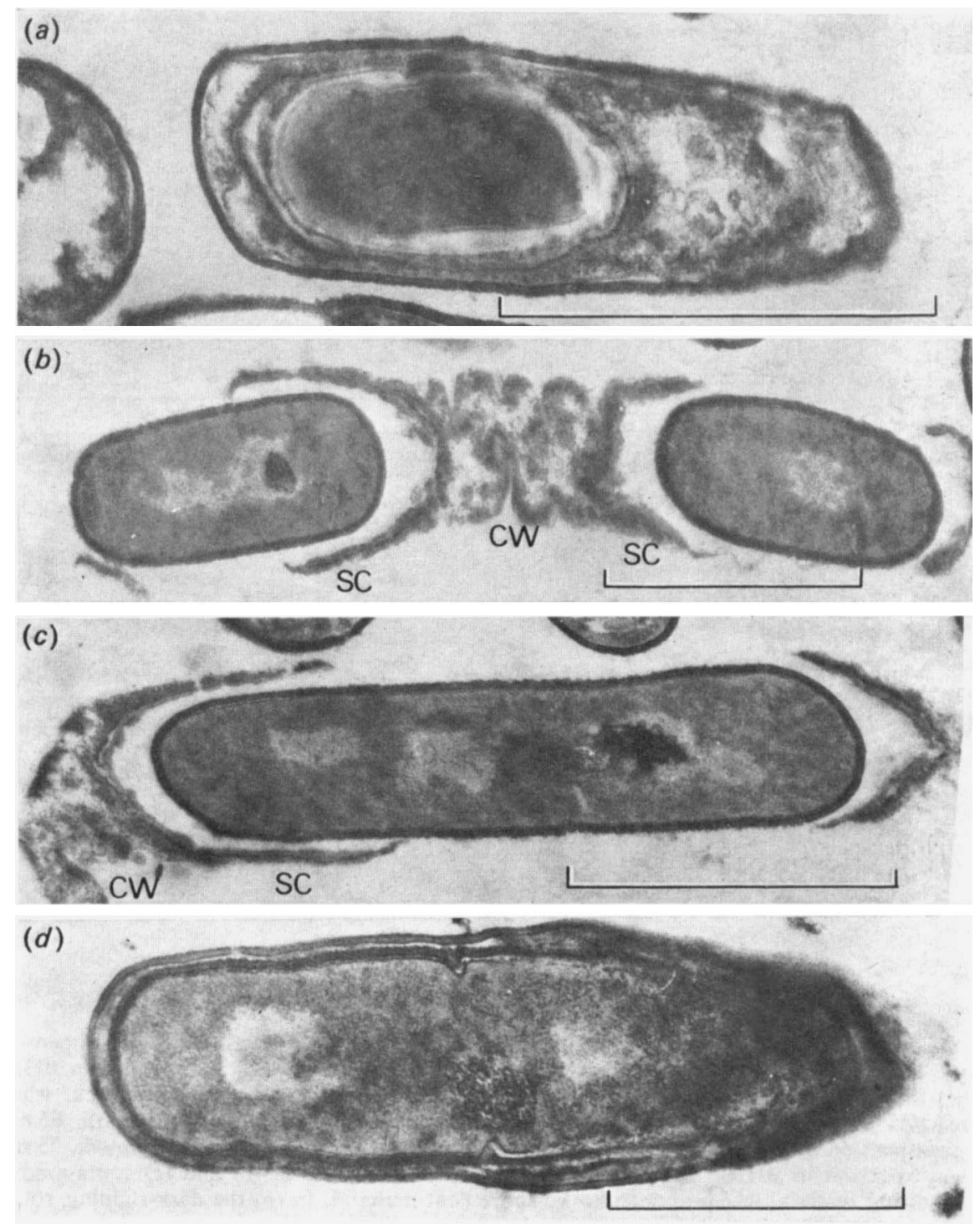

Fig. 4. Bacillus subtilis 168 was grown in $\mathrm{CH}$ medium at $42^{\circ} \mathrm{C}$ and transferred to resuspension medium also at $42^{\circ} \mathrm{C}$. At $t 3$ PMSF ( $4 \mathrm{mg} \mathrm{ml}^{-1}$ ) was added. At $t 8$ the PMSF crystals were removed, and bacteria were resuspended in $\mathrm{CH}$ medium and further incubated at $42^{\circ} \mathrm{C}$. Samples were fixed $75 \mathrm{~min}$ after resuspension in $\mathrm{CH}$ medium. (a) A prespore produced in the presence of PMSF before resuspension in $\mathrm{CH}$ medium appears to be blocked at stage V. Two sister prespores $(b)$ and a single prespore $(c)$ have outgrown and the newly developed cells have broken out of the spore coat (SC) and of the mother cell wall (CW). (d) An incipient septum is formed by a newly developed cell still inside the mother cell. Bar markers represent $1 \mu \mathrm{m}$.

\section{Effect of toluene on intrasporangial germination and outgrowth}

Bacteria were grown in $\mathrm{CH}$ medium at $37^{\circ} \mathrm{C}$ and transferred to resuspension medium also at $37^{\circ} \mathrm{C}$. At $t 4 \cdot 5$, a drop of toluene was added to $1 \mathrm{ml}$ of culture in a test tube. The tube was shaken for $1 \mathrm{~min}$, and toluene was expelled by bubbling air through the suspension for $1 \mathrm{~min}$. The cells were then resuspended in BHIB and further incubated at $37^{\circ} \mathrm{C}$. Intrasporangial germination and outgrowth, similar to those described above, were observed. 


\section{DISCUSSION}

We have already mentioned in the Introduction possible reasons why germination and outgrowth do not occur in the developing spore. These included the possibility that the cytoplasm of the mother cell contains an anti-germinant. Indeed, it has been proposed by Katz \& Demain (1977) that some sporulation-associated antibiotics might serve this function. Conversely, the membrane of the mother cell might exclude germinants that are in the medium. The effects both of cold-shock and of toluene treatment could be interpreted either as causing loss of a supposed anti-germinant or as allowing access of germinating agents. Henneberry \& Freese (1973) have shown that chilling may cause leakage of material from $B$. subtilis cells and also that it increases their permeability to components of the medium. The fact that PMSF produces similar effects does not help us to decide between the two possibilities we are considering.

The procedure adopted in the experiments with PMSF requires some comment. Dancer \& Mandelstam (1975) found that at $37^{\circ} \mathrm{C}$ sporulation becomes insensitive to PMSF at about $t 3$ (before the appearance of phase-grey spores at this temperature). Like these authors, we observed that the addition of PMSF when phase-grey spores began to appear (about $t 4$ at $37^{\circ} \mathrm{C}$ ) failed to block development of heat-resistance at $37^{\circ} \mathrm{C}$. However, the inhibitor added when a culture had reached a similar stage at $42^{\circ} \mathrm{C}$ (about $t 3$ ) did prevent development of heat-resistance at that temperature. A difference in solubility of PMSF at the two temperatures may account for the fact that sporulating cells remain sensitive for longer periods to saturating concentrations of the inhibitor at $42{ }^{\circ} \mathrm{C}$ than they do at $37^{\circ} \mathrm{C}$. For these reasons, the experiments with PMSF were done at $42^{\circ} \mathrm{C}$. The addition of PMSF, when the cultures contained about $10 \%$ phase-grey spores, blocked completion of development and also made the prespores capable of rapid intrasporangial germination and outgrowth. A direct role for serine protease in coat processing has been proposed in Bacillus cereus by Cheng \& Aronson (1977). These authors reported that a mutant of $B$. cereus with an alteration in the intracellular serine protease produced coat-deficient spores with altered germination properties. Aronson \& Fitz-James (1975) had observed earlier that coat-defective spores of mutants of $B$. cereus lose the ability to respond to germinants and tend to germinate spontaneously during storage at $4{ }^{\circ} \mathrm{C}$. This suggests that the normal coat layers may hinder or delay spontaneous germination. It is thus possible that in our experiments PMSF might promote intrasporangial germination by interfering with coat formation. It is equally possible that, like cold-shock and toluene treatment, PMSF alters sporangial permeability. It could thus provoke the loss of an intracellular anti-germinant, or else allow ingress of germinating agents from the medium.

During intrasporangial outgrowth, 'phase-bright ends' were seen before the rupture of the mother cell. We think that these structures may become visible as a consequence of intracellular pressure arising from extensive prespore elongation, which would press the cytoplasm of the mother cell and remnants of the spore coat and of the cortex against the mother cell wall; interaction between these cellular constituents could perhaps generate phase-brightness.

The electron microscope showed that during intrasporangial germination of cold-shocked prespores, spore coat material appears that was not there initially. Deposition of the inner coat layers begins at early stage IV in B. cereus (Aronson \& Fitz-James, 1976). Since synthesis of alkali-soluble coat protein begins at stage II, though deposition occurs only later (Wood, 1972), it seems likely that the coat formation that we observed during intrasporangial germination and outgrowth involves the continuation of a self-assembly process, rather than further biosynthesis.

Our observations and those of other authors (Sterlini \& Mandelstam, 1969; Cooney et al., 1977) suggest that intrasporangial germination can occur asynchronously when cells are resuspended in rich medium without any previous treatment. The overall effect of 
PMSF, cold-shock and toluene treatments is to accelerate prespore germination upon resuspension in rich medium, thus allowing intrasporangial germination to be identified and studied. Whether they do so by causing the loss of an intracellular anti-germinant or whether they allow ingress of germinating agents from the medium has to be determined. However, it is clear that the prespore has the ability to germinate and revert to vegetative growth while it is still contained within the sporangium.

We are grateful to Dr M. Young for helpful discussions and to Miss M. Bergin for technical help. P.D. gratefully acknowledges the receipt of a Rhodes Scholarship. The work was supported by the Science Research Council.

\section{REFEREN CES}

Aronson, A. I. \& Fitz-James, P. C. (1975). Properties of Bacillus cereus spore coat mutants. Journal of Bacteriology 123, 354-365.

Aronson, A. I. \& Fitz-JAMES, P. (1976). Structure and morphogenesis of the bacterial spore coat. Bacteriological Reviews 40, 360-402.

Cheng, Y.-S. E. \& Aronson, A. I. (1977). Alterations of spore coat processing and protein turnover in a Bacillus cereus mutant with a defective postexponential intracellular protease. Proceedings of the National Academy of Sciences of the United States of America 74, 1254-1258.

Cooney, P. H., Whiteman, P. F. \& Freese, E. (1977). Media dependence of commitment in Bacillus subtilis. Journal of Bacteriology 129, 901-907.

Dancer, B. N. \& Mandelstam, J. (1975). Production and possible function of serine protease during sporulation of Bacillus subtilis. Journal of Bacteriology 121, 406-410.

Ellar, D. J., Eaton, M. W., Hogarth, C., WilKinson, B. J., Deans, J. \& La Nauze, J. (1975). Comparative biochemistry and function of forespore and mother cell compartments during sporulation of Bacillus megaterium cells. In Spores VI, pp. 425-433. Edited by P. Gerhardt, R. N. Costilow \& H. L. Sadoff. Washington, D.C.: American Society for Microbiology.

Freese, E. B. \& FreEse, E. (1977). The influence of the developing spore on the mother cell. Developmental Biology 60, 453-462.
Frehel, C. \& Ryter, A. (1969). Réversibilité de la sporulation chez Bacillus subtilis. Annales de l'Institut Pasteur 117, 297-311.

Henneberry, R. C. \& Freese, E. (1973). Temperature-dependent permeability changes of Bacillus subtilis and incorporation of nucleotides into DNA. Biochemical and Biophysical Research Communications 55, 788-797.

Katz, E. \& Demain, G. (1977). The peptide antibiotics of Bacillus: chemistry, biogenesis, and possible functions. Bacteriological Reviews 41, 449-474.

KAY, D. \& WARREN, S. C. (1968). Sporulation in Bacillus subtilis. Morphological changes. Biochemical Journal 109, 819-824.

Lundgren, D. G., Karp, D. F. \& LANG, D. R. (1969). Structure-function relationships in bacterial sporulation. In Spores IV, pp. 20-38. Edited by L. L. Campbell. Bethesda, Md: American Society for Microbiology.

RYTER, A. (1965). Étude morphologique de la sporulation de Bacillus subtilis. Annales de l'Institut Pasteur 108, 40-60.

Sterlini, J. M. \& Mandelstam, J. (1969). Commitment to sporulation in Bacillus subtilis and its relationship to development of actinomycin resistance. Biochemical Journal 113, 29-37.

WoOD, D. A. (1972). Sporulation in Bacillus subtilis. Properties and time of synthesis of alkali-soluble protein of the spore coat. Biochemical Journal 130, 505-514. 